\title{
Interference of Grasses on the Growth of Eucalyptus Clones
}

\author{
Fernanda Campos Mastrotti Pereira ${ }^{1}$, Pedro Luis da Costa Aguiar Alves $^{1} \&$ José Valcir Fidelis Martins $^{1}$ \\ ${ }^{1}$ Faculdade de Ciências Agrárias e Veterinárias da Universidade Estadual Paulista Julio de Mesquita Filho \\ Correspondence: Fernanda Campos Mastrotti Pereira, Faculdade de Ciências Agrárias e Veterinárias da \\ Universidade Estadual Paulista Julio de Mesquita Filho. E-mail: fernandamastrotti@hotmail.com
}

Received: August 13, 2013 Accepted: September 22, 2013 Online Published: October 15, 2013

doi:10.5539/jas.v5n11p173 URL: http://dx.doi.org/10.5539/jas.v5n11p173

\begin{abstract}
This experiment aimed to study the interference of Urochloa decumbens, Brachiaria plantaginea, Brachiaria ruziziensis and Panicum maximum (100 plants $\mathrm{m}^{-2}$ density), on the initial growth of clones of eucalyptus (Eucalyptus urograndis) clones 1, 2, 3, 4 and 5. Each pot had one plant of eucalyptus and five weed plants. The experimental design was completely randomized with four replications, constituting a $5 \times 5$ factorial design. The height and the diameter of eucalyptus plants were evaluated at $0,15,28,41$ and 50 days after weeds transplanting (DAT). At 50 DAT was measured the foliar area of eucalyptus plants, as well as the dry mass of eucalyptus plants (leaves and stem) and the dry mass of weeds. The five clones suffered negative interference during the coexistence with weeds. The clones showed different behaviors through the interaction with weeds. For the more susceptible characteristics to interference - leaves and stem dry mass - eucalyptus clones 3, 4 and 5 were more sensitive to the presence of weeds.
\end{abstract}

Keywords: Brachiaria sp., competition, coexistence, Eucalyptus urograndis, Panicum maximum

\section{Introduction}

In Brazil, the forestry sector is represented by more than six and a half million hectares. It is estimated that the total reforested areas, 78 per cent are planted with Eucalyptus species (Associação Brasileira de Produtores de Florestas Plantadas - ABRAF, 2012).

The success of a forest enterprise is achieved when the implantation and initial training of forest are made correctly, using good agricultural practices. Among these practices, weed management has a fundamental importance, since the presence and the possible interference of weeds can be a limiting factor to crop growth.

The weed interference in forest plantations, especially in eucalyptus, is more severe in the early stages of growth until about a year old (Pitelli \& Marchi, 1988). Among the effects of competition between weeds and eucalyptus plants is decreased productivity, which can be observed through the reduction of variables such as diameter and height. The presence of competing species, in addition to reflecting a decrease in quantity, can compromise the quality of the obtained products (Costa, Alves, \& Pavani, 2004).

The expansion of the forestry sector to areas previously cultivated with pastures, especially Urochloa decumbens (syn. Brachiaria decumbens) (Toledo et al., 1999), made the grasses the major weed species in eucalyptus plantation. Its potential infestation, competition and aggressiveness are great, and the control is very difficult (Toledo et al. 1999). However, the presence of other grasses, such as perennial species of the genus Panicum has also caused damage in the growth early stages of forest species (Dinardo et al., 2003; Cruz et al., 2010).

The coexistence of eucalyptus plants and Urochloa decumbens in densities exceeding 4 plants $\mathrm{m}^{-2}$ led to average reductions of 55, 55 and 63 per cent for leaves dry mass, stem dry mass and foliar area, respectively, at 90 days after eucalyptus seedlings planting (Toledo et al., 2001). The presence of Panicum maximum at the densities from 4 plants $\mathrm{m}^{-2}$ reduced leaves dry mass, stem dry mass and foliar area at approximately 20, 44 and 33 per cent, respectively, at 110 days after eucalyptus seedlings planting (Dinardo et al., 2003).

The hypothesis of this study is that the presence of weeds can interfere negatively on the eucalyptus clones growth, restricting characteristics such height, diameter, foliar area, dry masses and, consequently, the yield. So, the evaluation of possible differences among clones growth related to different weed species is of great interest. 
The present study aimed to investigate the influence of Urochloa decumbens Stapf. (syn. Brachiaria decumbens Stapf.), Brachiaria plantaginea (Link) Hitch, Brachiaria ruziziensis R. Germ. \& Evrard e Panicum maximum Jacq. on growth characteristics of Eucalyptus urograndis clones.

\section{Material and Methods}

An experiment was conducted between November of 2010 (planting date) and February of 2011 using pots with 5 liters of capacity - previously filled with Red-Dark Latossoil - outdoors and unprotected. Physical and chemical analyzes showed the results: clay texture, $\mathrm{pH}_{\mathrm{CaCl}}$ of $6.0,21.0 \mathrm{~g} \mathrm{dm}^{-3}$ of organic matter, $66 \mathrm{mg} \mathrm{dm}^{-3}$ of $\mathrm{P}$ resin, $\mathrm{K}$, $\mathrm{Ca}, \mathrm{Mg}$ and $\mathrm{Al}+\mathrm{H}$ of 4.3, 49.0, 28.0 and $18.0 \mathrm{mmol} \mathrm{dm}^{-3}$, respectively, and base saturation of 82 per cent. Based on these analyzes the need for plants fertilization was calculated.

Five clones of Eucalyptus urograndis (although all are result of E. grandis W. Hill ex. Maiden with E. urophylla S.T. Blake interbreeding, they are result of different programs, thus having different characteristics, such as degree of disease and water stress tolerance, leaf shape and architecture, among other) identified as clone 1, 2, 3, 4 and 5 was used. At the time of plantation, the average height and diameter of clones was $25.5 \mathrm{~cm}$ and $3.2 \mathrm{~cm}$, respectively.

We used Urochloa decumbens (syn. Brachiaria decumbens) (BRADC), B. plantaginea (Link) Hitch (BRAPL), B. ruziziensis R. Germ. \& Evrard (BRARZ) and Panicum maximum Jacq. (PANMA). These species were chosen because theye are commonly found in reforestation areas, since the state of São Paulo current areas of eucalyptus plantations were formerly pasture, justifying the abundant presence of these species.

Weeds seedlings were obtained from seeding in polystyrene trays containing substrate for vegetables. At the transplant time, the weeds seedlings were between 2 and 4 leaves. About 90 days after transplantation of eucalyptus seedlings in pots, were added 5 seedlings of each species of weed per pot. At the time of weed planting, the average diameter ant height of clones was $82.3 \mathrm{~cm}$ and $8.82 \mathrm{~cm}$, respectively. The time between eucalyptus seedlings planting and weeds planting aimed to represent a situation in which a pre-emergent herbicide was applied, controlling the weed community for 60 days. The 30 remaining days represented the period of establishment of weeds, totaling the period referred above. Thus, each pot contains one eucalyptus plant and five plants of the same weed, simulating a density of 100 plants $\mathrm{m}^{-2}$.

The experimental design was a complete randomized block with four replications in a factorial $5 \times 5$, with 5 clones of eucalyptus and 5 treatments (4 weed species and one weed free control for each clone). At 0, 15, 28, 41 and 50 days after weeds transplanting (DAT) height and diameter of eucalyptus plants were measured. At 50 DAT foliar area, leaves and stem dry mass of eucalyptus plants and shoot dry mass of weeds were determined. For this, the plants were dried $\left(65 \pm 3{ }^{\circ} \mathrm{C}\right)$ for 7 days. The collected data were processed to percentage, considering the weed free control (free of coexistence) as 100 per cent, aiming to unify the different clones. After this, the data were subjected to variance analysis. In cases of significant $F$ test, the means were compared by Tukey test at 5 per cent of probability (Sisvar $\left.{ }^{\circledR}\right)$.

\section{Results and Discussion}

The eucalyptus initial growth variance analysis indicated that the presence of weeds influenced significantly their height, diameter, foliar area and dry masses.

The differences in height and diameter at 0 and 28 days are probably due to genetic variations of the characteristics of the different clones. In this evaluation the differences between height and diameter reached at most 3 per cent, indicating that at that time, the competition was not established yet.

The weed species coexisted with all clones and caused significant reductions in height, these being more pronounced at 41 and 50 days after weeds transplanting (DAT). The clone 2 presented more negative interference, showing greater height reduction compared to other clones at 28, 41 and 50 DAT, presenting 10 per cent lower compared to weed free control in the last evaluation.

Cruz et al. (2010) also found distinct effects on different clones competition, reporting the effect and degree of interference may vary by species and intraspecific categories. Yet according to the authors, despite being clones from same species, their seedlings exhibit different behaviors under competition with P. maximum.

The coexistence of eucalyptus clones with Urochloa decumbens, B. plantaginea, B. ruziziensis e Panicum maximum promoted an average reduction of $8,7,9$ and 8 per cent in eucalyptus plants height at 50 DAT (Table 1). 
Table 1. Effect of $U$. decumbens (BRADC), B. plantaginea (BRAPL), B. ruziziensis (BRARZ) and P. maximum (PANMA) on eucalyptus clones height (relative percentage) at 41 and 50 days after weeds transplanting

\begin{tabular}{|c|c|c|c|c|c|}
\hline \multicolumn{6}{|c|}{ Height at 41 DAT } \\
\hline Clones & $\begin{array}{c}\text { Free weed } \\
\text { control }\end{array}$ & BRADC & BRAPL & BRARZ & PANMA \\
\hline Clone 1 & $100.0^{1} \mathrm{~A} a$ & $98.1 \mathrm{~A} \mathrm{a}$ & $94.0 \mathrm{~A} \mathrm{a}$ & $91.2 \mathrm{~B} \mathrm{a}$ & $95.1 \mathrm{AB} a$ \\
\hline Clone 2 & $100.0 \mathrm{~A} \mathrm{a}$ & $95.1 \mathrm{~A} \mathrm{ab}$ & $90.7 \mathrm{~A} \mathrm{ab}$ & 85.9B ab & $81.3 \mathrm{~B} \mathrm{~b}$ \\
\hline Clone 3 & $100.0 \mathrm{~A} \mathrm{a}$ & $99.1 \mathrm{~A} \mathrm{a}$ & $93.2 \mathrm{~A} \mathrm{a}$ & $93.6 \mathrm{~B} \mathrm{a}$ & $101.0 \mathrm{~A} \mathrm{a}$ \\
\hline Clone 4 & $100.0 \mathrm{~A} \mathrm{ab}$ & $98.4 \mathrm{~A} \mathrm{ab}$ & $93.1 \mathrm{~A} \mathrm{~b}$ & $100.2 \mathrm{~A} \mathrm{a}$ & $99.8 \mathrm{~A} \mathrm{ab}$ \\
\hline Clone 5 & $100.0 \mathrm{~A} \mathrm{a}$ & $92.8 \mathrm{~A} \mathrm{a}$ & $96.2 \mathrm{~A} \mathrm{a}$ & $96.0 \mathrm{~B} \mathrm{a}$ & $93.2 \mathrm{AB}$ a \\
\hline \multicolumn{6}{|c|}{ Height at 50 DAT } \\
\hline Clones & $\begin{array}{c}\text { Free weed } \\
\text { control }\end{array}$ & BRADC & BRAPL & BRARZ & PANMA \\
\hline Clone 1 & $100.0 \mathrm{~A} \mathrm{a}$ & $92.4 \mathrm{~A} \mathrm{bc}$ & $91.1 \mathrm{~A} \mathrm{bc}$ & $88.1 \mathrm{~B} \mathrm{c}$ & $94.8 \mathrm{~A} \mathrm{ab}$ \\
\hline Clone 2 & $100.0 \mathrm{~A} \mathrm{a}$ & $92.9 \mathrm{~A} \mathrm{~b}$ & $94.1 \mathrm{~A} \mathrm{ab}$ & $81.5 \mathrm{C} \mathrm{c}$ & $82.4 \mathrm{~B} \mathrm{c}$ \\
\hline Clone 3 & $100.0 \mathrm{~A} \mathrm{a}$ & $93.4 \mathrm{~A} \mathrm{~b}$ & $91.8 \mathrm{~A} \mathrm{~b}$ & $93.6 \mathrm{AB} \mathrm{b}$ & $93.6 \mathrm{~A} \mathrm{~b}$ \\
\hline Clone 4 & $100.0 \mathrm{~A} \mathrm{a}$ & $90.4 \mathrm{~A} \mathrm{~b}$ & $91.3 \mathrm{~A} \mathrm{~b}$ & $93.5 \mathrm{AB} \mathrm{b}$ & $95.8 \mathrm{~A} \mathrm{ab}$ \\
\hline Clone 5 & $100.0 \mathrm{~A} \mathrm{a}$ & $91.4 \mathrm{~A} \mathrm{~b}$ & $95.5 \mathrm{~A} \mathrm{ab}$ & $97.4 \mathrm{~A} \mathrm{ab}$ & $92.7 \mathrm{~A} \mathrm{~b}$ \\
\hline
\end{tabular}

${ }^{1}$ Data converted to percentage compared to the weed free control.

Means followed by different letters differ significantly by Tukey test at $5 \%$ probability. Capital letters compare weeds and lower-case letters compare clones.

At 41 and 50 DAT $U$. decumbens e B. plantaginea promoted similar effects at the height of all clones. Already, $B$. ruziziensis e $P$. maximum promoted different effects depending on which clone coexist. Height showed less sensitivity to weed interference, which has been also previously reported (Zen, 1987; Pitelli \& Marchi, 1988).

The coexistence with weeds interferes negatively about the diameter of eucalyptus plants. The clone 4 showed reductions of 14.1 and 13.6 per cent in diameter, at 41 and 50 DAT, respectively, duo the weeds coexistence (Table 2). Already, the clones 1 and 5 were less affected by coexistence, with its diameter reduced by less than 6 per cent, compared to free weed control. At 50 DAT, was observed the highest restrictions for this feature, which ranged between 11 and 13 per cent, with the highest percentage attributed to the coexistence of eucalyptus plants with $B$. ruziziensis. However, at 28, 41 and 50 DAT effects of weed species in diameter of eucalyptus plants were not observed. 
Table 2. Effect of $U$. decumbens (BRADC), B. plantaginea (BRAPL), B. ruziziensis (BRARZ) and P. maximum (PANMA) on eucalyptus clones diameter (relative percentage) at 41 and 50 days after weeds transplanting

\begin{tabular}{cccccc}
\hline \multicolumn{5}{c}{ Diameter at 41 DAT } \\
\hline Clones & $\begin{array}{c}\text { Free weed } \\
\text { control }\end{array}$ & BRADC & BRAPL & BRARZ & PANMA \\
\hline Clone 1 & $100.0^{1} \mathrm{~A} \mathrm{a}$ & $90.5 \mathrm{~A} \mathrm{~b}$ & $91.3 \mathrm{~A} \mathrm{~b}$ & $88.3 \mathrm{BC} \mathrm{b}$ & $88.7 \mathrm{C} \mathrm{b}$ \\
Clone 2 & $100.0 \mathrm{~A} \mathrm{a}$ & $94.0 \mathrm{~A} \mathrm{ab}$ & $95.4 \mathrm{~A} \mathrm{ab}$ & $89.8 \mathrm{BC} \mathrm{b}$ & $93.4 \mathrm{BC} \mathrm{b}$ \\
Clone 3 & $100.0 \mathrm{~A} \mathrm{a}$ & $91.9 \mathrm{~A} \mathrm{c}$ & $94.1 \mathrm{~A} \mathrm{bc}$ & $91.3 \mathrm{~A} \mathrm{bc}$ & $100.7 \mathrm{~A} \mathrm{a}$ \\
Clone 4 & $100.0 \mathrm{~A} \mathrm{a}$ & $83.8 \mathrm{~B} \mathrm{bc}$ & $82.7 \mathrm{~B} \mathrm{bc}$ & $84.7 \mathrm{C} \mathrm{b}$ & $78.2 \mathrm{C} \mathrm{c}$ \\
Clone 5 & $100.0 \mathrm{~A} \mathrm{a}$ & $92.8 \mathrm{~A} \mathrm{c}$ & $94.4 \mathrm{~A} \mathrm{ab}$ & $97.0 \mathrm{~A} \mathrm{ab}$ & $98.1 \mathrm{AB} \mathrm{ab}$ \\
\hline \multirow{2}{*}{ Clones } & Free weed & BRADC & BRAPL & BRARZ & PANMA \\
\hline Clone 1 & $100.0 \mathrm{~A} \mathrm{a}$ & $90.5 \mathrm{~A} \mathrm{~b}$ & $90.6 \mathrm{~A} \mathrm{~b}$ & $92.0 \mathrm{~A} \mathrm{~b}$ & $97.6 \mathrm{~A} \mathrm{ab}$ \\
Clone 2 & $100.0 \mathrm{~A} \mathrm{a}$ & $94.0 \mathrm{~A} \mathrm{ab}$ & $90.8 \mathrm{~A} \mathrm{~b}$ & $88.0 \mathrm{BC} \mathrm{bc}$ & $82.1 \mathrm{CD} \mathrm{c}$ \\
Clone 3 & $100.0 \mathrm{~A} \mathrm{a}$ & $91.9 \mathrm{~A} \mathrm{c}$ & $86.1 \mathrm{~A} \mathrm{~b}$ & $78.1 \mathrm{D} \mathrm{c}$ & $89.3 \mathrm{BC} \mathrm{b}$ \\
Clone 4 & $100.0 \mathrm{~A} \mathrm{a}$ & $83.8 \mathrm{~B} \mathrm{bc}$ & $84.0 \mathrm{~A} \mathrm{bc}$ & $81.4 \mathrm{CD} \mathrm{bc}$ & $79.2 \mathrm{D} \mathrm{c}$ \\
Clone 5 & $100.0 \mathrm{~A} \mathrm{a}$ & $92.8 \mathrm{~A} \mathrm{~b}$ & $86.5 \mathrm{~A} \mathrm{c}$ & $98.6 \mathrm{~A} \mathrm{ab}$ & $96.5 \mathrm{AB} \mathrm{ab}$ \\
\hline
\end{tabular}

${ }^{1}$ Data converted to percentage compared to the weed free control.

Means followed by different letters differ significantly by Tukey test at $5 \%$ probability. Capital letters compare weeds and lower-case letters compare clones.

At 41 and 50 DAT all weeds species resulted different effects, depending on the clone with witch coexisted. $P$. maximum was the species more restrictive to the diameter growth of clone 4, reaching up to 22 per cent for this variable restriction in both evaluations cited above (Table 2).

Different responses to height and diameter reductions of eucalyptus clones in competitive situations were observed by Schweitzer et al. (1999) and Coll et al. (2004). These different effects can be explained by a different priority in allocation related to apical or cambial growth.

Under field conditions, the weed densities may be highter than the experiment, or the coexistence period greater than taken under consideration, thus the results may be similar or higher than observed in the study.

For foliar area, dry mass of leaves and stem dry mass differences among clones were observed, independently of species that the clones coexisted (Table 3 ). The foliar area of clone 4 was about 28 per cent lower when compared with weed free control, while clone 2 has been less affected by coexistence of weeds, with a reduction of approximately 5 per cent for this characteristic. Already, clone 1 had dry mass of leaves 22.8 per cent lower when compared to the weed free control. For the same feature, the remaining clones showed reductions between 14.6 and 19.3 per cent. The presence of weeds had severe inimical effect on stem dry mass for all clones. For clones 1 and 2 the reduction was 22.3 and 24.3 per cent, respectively. Although with a lower percentage of growth restriction, other clones showed stem dry mass between 13.7 and 15.9 per cent lower than free weeds control. 
Table 3. Effect of $U$. decumbens (BRADC), B. plantaginea (BRAPL), B. ruziziensis (BRARZ) and P. maximum (PANMA) on eucalyptus clones foliar area and leaves and stem dry masses (relative percentage) at 50 days after weeds transplanting

\begin{tabular}{|c|c|c|c|c|c|}
\hline \multicolumn{6}{|c|}{ Foliar area at 50 DAT } \\
\hline Clones & $\begin{array}{c}\text { Free weed } \\
\text { control }\end{array}$ & BRADC & BRAPL & BRARZ & PANMA \\
\hline Clone 1 & $100.0^{1} \mathrm{~A} \mathrm{a}$ & $75.1 \mathrm{~A} \mathrm{~b}$ & $85.3 \mathrm{AB} a b$ & 82.0AB ab & $85.5 \mathrm{AB} \mathrm{ab}$ \\
\hline Clone 2 & $100.0 \mathrm{~A} \mathrm{a}$ & $90.4 \mathrm{~A} \mathrm{a}$ & $94.6 \mathrm{~A} a$ & $93.3 \mathrm{~A} \mathrm{a}$ & $95.6 \mathrm{~A} \mathrm{a}$ \\
\hline Clone 3 & $100.0 \mathrm{~A} \mathrm{a}$ & $90.4 \mathrm{~A} \mathrm{a}$ & $94.0 \mathrm{~A} \mathrm{a}$ & $91.0 \mathrm{~A} \mathrm{a}$ & $88.5 \mathrm{~A}$ ba \\
\hline Clone 4 & $100.0 \mathrm{~A} \mathrm{a}$ & $67.5 \mathrm{~B} \mathrm{c}$ & $72.4 \mathrm{~B} \mathrm{~b}$ & $65.0 \mathrm{~B} \mathrm{bc}$ & $74.7 \mathrm{~B} \mathrm{~b}$ \\
\hline Clone 5 & $100.0 \mathrm{~A} \mathrm{a}$ & $82.8 \mathrm{~A} \mathrm{a}$ & $92.6 \mathrm{AB}$ a & $89.0 \mathrm{~A} \mathrm{a}$ & $81.2 \mathrm{~A} \mathrm{ba}$ \\
\hline \multicolumn{6}{|c|}{ Leaves dry mass at 50 DAT } \\
\hline Clones & $\begin{array}{c}\text { Free weed } \\
\text { control }\end{array}$ & BRADC & BRAPL & BRARZ & PANMA \\
\hline Clone 1 & $100.0 \mathrm{~A} \mathrm{a}$ & $61.5 \mathrm{~B} \mathrm{c}$ & $62.0 \mathrm{~B} \mathrm{c}$ & $80.9 \mathrm{~A} \mathrm{~b}$ & $81.4 \mathrm{~B} \mathrm{~b}$ \\
\hline Clone 2 & $100.0 \mathrm{~A} \mathrm{a}$ & $77.9 \mathrm{~A} \mathrm{bc}$ & $78.0 \mathrm{AB} \mathrm{c}$ & $67.5 \mathrm{~B} \mathrm{c}$ & $80.3 \mathrm{~B} \mathrm{~b}$ \\
\hline Clone 3 & $100.0 \mathrm{~A} \mathrm{a}$ & $81.9 \mathrm{~A} \mathrm{bc}$ & $87.5 \mathrm{~A} \mathrm{~b}$ & $72.1 \mathrm{AB} \mathrm{c}$ & $79.5 \mathrm{~B} \mathrm{bc}$ \\
\hline Clone 4 & $100.0 \mathrm{~A} \mathrm{a}$ & $79.9 \mathrm{~A} \mathrm{~b}$ & $79.8 \mathrm{~A} \mathrm{~b}$ & $73.3 \mathrm{AB} \mathrm{b}$ & $93.8 \mathrm{~A} \mathrm{a}$ \\
\hline Clone 5 & $100.0 \mathrm{~A} \mathrm{a}$ & 72.7AB cd & $86.4 \mathrm{~A} \mathrm{~b}$ & $65.0 \mathrm{~B} \mathrm{~d}$ & $83.5 \mathrm{~B} \mathrm{bc}$ \\
\hline \multicolumn{6}{|c|}{ Stem dry mass at 50 DAT } \\
\hline Clones & $\begin{array}{c}\text { Free weed } \\
\text { control }\end{array}$ & BRADC & BRAPL & BRARZ & PANMA \\
\hline Clone 1 & $100.0 \mathrm{~A} \mathrm{a}$ & $63.0 \mathrm{~B} \mathrm{~d}$ & $62.5 \mathrm{~B} \mathrm{~d}$ & $75.8 \mathrm{BC} \mathrm{c}$ & $87.3 \mathrm{~A} \mathrm{~b}$ \\
\hline Clone 2 & $100.0 \mathrm{~A} \mathrm{a}$ & $64.2 \mathrm{D} \mathrm{b}$ & $67.8 \mathrm{CD} \mathrm{d}$ & $72.1 \mathrm{~B} \mathrm{~b}$ & $72.1 \mathrm{~B} \mathrm{~b}$ \\
\hline Clone 3 & $100.0 \mathrm{~A} \mathrm{a}$ & $83.1 \mathrm{~B} \mathrm{bc}$ & $89.1 \mathrm{~A} \mathrm{~b}$ & $83.1 \mathrm{~B} \mathrm{bc}$ & $76.2 \mathrm{~B} \mathrm{c}$ \\
\hline Clone 4 & $100.0 \mathrm{~A} \mathrm{a}$ & $84.1 \mathrm{~A} \mathrm{~b}$ & 79.9AB b & $77.6 \mathrm{BC} \mathrm{b}$ & $79.1 \mathrm{AB} \mathrm{b}$ \\
\hline Clone 5 & $100.0 \mathrm{~A} \mathrm{a}$ & $77.5 \mathrm{~A} \mathrm{~b}$ & $75.3 \mathrm{BC} \mathrm{b}$ & $85.1 \mathrm{~A} \mathrm{a}$ & $76.6 \mathrm{~B} \mathrm{~b}$ \\
\hline
\end{tabular}

${ }^{1}$ Data converted to percentage compared to the weed free control.

Means followed by different letters differ significantly by Tukey test at $5 \%$ probability. Capital letters compare weeds and lower-case letters compare clones.

Through the weeds coexistence with clones, it was possible to observe effects dependents of weed species (Table 3). Although all species had foliar area limited when compared with weed free control. U. decumbens was responsible for 22 per cent of reduction in this characteristic, while for the coexistence of eucalyptus plants with other weed species restricted average 15 per cent.

Upon studying weed-eucalyptus interaction, it was possible to observe effects dependent of weeds species (Table 3). Although all species had foliar area limited when compared to weed free control. U. decumbens was responsible for reduction by 22 per cent, while for the coexistence of eucalyptus plants with other weed species restricted average 15 per cent.

As for leaves dry mass all species were quite aggressive, causing reductions between 16.2 and 28.2 per cent, and $B$. ruziziensis was the most aggressive species. For stem dry mass, all species have interfered negatively for this character, even $U$. decumbens and B. plantaginea caused approximately 26 per cent of reduction.

Dinardo et al. (2003) used weeds densities of 0, 4, 8, 16 and 20 P. maximum plants $\mathrm{m}^{-2}$, and reported that densities from 4 plants $\mathrm{m}^{-2}$, even though considered low densities, were enough to lead to reductions of 20 and 61 per cent for number of leaves and number of branches, respectively. 
Significant interactions for foliar area and dry masses were observed in the presence of all weed species (Table 3). Clone 4 had its foliar area severely reduced in the presence of all species, mainly from $U$. decumbens and B. ruziziensis.

To dry mass of leaves, clone 1 was very sensitive due to interference of $U$. decumbens and B. plantaginea, and this variable was reduced by 38.5 and 38 per cent, respectively, when compared to weed free control. For stem dry mass, clone 1 was affected by coexistence, especially with $U$. decumbens and $B$. plantaginea, causing restrictions of 37 and 37.5 per cent, and 35.8 and 32.8 per cent for clone 2 . This data showed the greatest sensitivity to the weeds presence, because most clones showed at least 25 per cent of reductions on stem dry mass at the presence of any evaluated species.

Analyzing weeds dry mass data, it was observed that weed species that presented more growth over the cohabitation period resulted in major reductions in the dry masses (Table 4). In coexistence with clone $1, B$. plantaginea accumulated the highest mass and was responsible for major reductions in diameter and leaves and stem dry mass. As for clones 2 and 3, B. ruziziensis and B. plantaginea showed greater development, emerging as major competitors and causes reductions on height, diameter and leaves dry mass.

Table 4. P. maximum, B. ruzuziensis, $U$. decumbens e B. plantaginea dry masses, after 50 days of cohabitation with Eucalyptus clones

\begin{tabular}{cccccc}
\hline \multicolumn{7}{c}{ Weeds dry mass at 50 DAT $\left(\mathbf{g ~ p o t}^{-1}\right)$} \\
\hline Weeds & Clone 1 & Clone 2 & Clone 3 & Clone 4 & Clone 5 \\
\hline PANMA & $23.90^{1} \mathrm{ab}$ & $16.94 \mathrm{c}$ & $23.55 \mathrm{~b}$ & $10.64 \mathrm{~b}$ & $20.88 \mathrm{ab}$ \\
BRARZ & $18.57 \mathrm{~b}$ & $32.19 \mathrm{a}$ & $26.74 \mathrm{ab}$ & $20.94 \mathrm{a}$ & $22.93 \mathrm{ab}$ \\
BRADC & $20.88 \mathrm{ab}$ & $25.58 \mathrm{~b}$ & $24.12 \mathrm{~b}$ & $12.60 \mathrm{~b}$ & $26.09 \mathrm{a}$ \\
BRAPL & $26.67 \mathrm{a}$ & $29.12 \mathrm{ab}$ & $30.95 \mathrm{a}$ & $13.90 \mathrm{~b}$ & $17.98 \mathrm{~b}$ \\
\hline F & $0.016^{*}$ & $0.001^{*}$ & $0.02^{*}$ & $0.001^{*}$ & $0.027^{*}$ \\
VC (\%) & 13.91 & 11.95 & 11.73 & 16.12 & 14.94 \\
\hline
\end{tabular}

Means followed by different letters differ significantly by Tukey test at $5 \%$ probability.

The dry mass of weeds that coexisted with clone 4 was much lower than the weeds dry mass accumulated in coexistence with the other clones. However, this clone was quite restricted growth, and B. ruziziensis excelled in promoting leaves growth reductions, reflecting in foliar area and leaves dry mass reductions.

For clone 5, U. decumbens, B. ruziziensis and P. maximum accumulated the largest dry mass, producing a negative impacting in all growth characteristics evaluated. Cruz et al. (2010) and Toledo et al. (2001) observed that aggressive annual species such as Panicum maximum and $U$. decumbens are more competitive at the first stage of Eucalyptus sp. growth.

Although all plants used are the result of Eucalyptus grandis with Eucalyptus urophylla crossing, the clones had distinct characteristics, such as initial height, leaf distribution and size of leaves.

The great influence of the presence of grasses in the reductions in height and diameter can be explained by the fact that the grasses roots grow very fast, exploring the soil moisture and nutrients better. Furthermore, their high aggressiveness allows a quickly colonization of the area (Toledo et al., 1996).

Height and diameter reduction are commonly reported and occur initially in the first year after eucalyptus plantation (Pitelli \& Marchi, 1988). Evaluating eucalyptus plants in early growth stages living with P. maximum and $U$. decumbens, observed that eucalyptus plants were negatively affected by weeds competition, suffering growth reductions in densities from 4 weeds $\mathrm{m}^{-2}$ (Dinardo et al., 2003; Toledo et al., 1999).

According Garau et al. (2009) the presence of weeds were a serious threat to the seedlings development of $E$. globulus subsp. Maideniii.. The effects of interspecific competition had strong influences on height, stem diameter, foliar area and individual volume of eucalyptus trees. Also according to these authors, the coexistence of eucalyptus plants with a weed community composed mainly of Cyperus esculentus resulted on reductions of up to 95 per cent of plants foliar area. 
Working with transplanted seedlings, Toledo et al. (2000) found that E. urophylla had to remain free of weeds interference (on a weed community composed mainly by U. decumbens and Spermacoce latifolia) until 140 days after seedlings planting. Already Cruz et al. (2010), studying the interference of P. maximum in five different clones of eucalyptus, said that all the clones suffered negative influence of weed coexistence. The clone 3 was the most sensitive to interaction with P. maximum, and the clone 1, the more tolerant. However, Souza et al. (2010) found for field conditions and for a weed community with predominance of $U$. decumbens and $P$. maximum interfered a little in growth, diameter and nutritional status of $E$. grandis plants.

Brendolan et al. (2000) evaluated eucalyptus inter and intraspecific competition found no effects on height, number of leaves and branches, observing a period of 60 days of coexistence with weeds. The lack of competition is probably due to the shot period studied, whereas other authors reported that the period of weed interference in eucalyptus begins at 30 days after plantation. In this case, the period of coexistence with the weeds was only 30 days, and the weeds were born in the area, exerting a small competitive pressure on eucalyptus plants.

The planting of weeds was done 90 days after planting of eucalyptus seedlings, allowing the eucalyptus be established free of competition. If the experiment does not reproduce a condition where a pre-emergent herbicide was applied, the interference of the weed community on eucalyptus plants occur soon after seedlings planting, and probably, the interference would be even greater.

In an experiment conducted in pots, likely competition for water, nutrients, light and space was even more pronounced, thereby weeds interference on eucalyptus, justifying the reductions percentages observed.

Water stress, for example, may have occurred at some point, since the water contain retained by the substrate may not have been enough to supply the water need of eucalyptus plants and grasses plants, creating a situation of competition for this limiting factor to plants growth.

Thus, further studies assessing the efficiency of water and nutrients use by different clones of Eucalyptus are needed.

\section{Conclusion}

The five clones of eucalyptus suffered negative interference during the period of coexistence with the weeds species studied. Urochloa decumbens, Brachiaria plantaginea and Brachiaria ruziziensis were the species that most reduce the initial growth of eucalyptus plants. However, the negative effects promoted by the presence of weeds were different for each clone, proving the importance of proper allocation of different clones in different locations needs.

\section{References}

ABRAF. Anuário estatístico da ABRAF. (2012). Ano base 2011. Retrieved from http://www.abraflor.org.br/estatisticas/ABRAF12/ABRAF12-BR.pdf

Brendolan, R. A., Pellegrini, M. T., \& Alves, P. L. C. A. (2000). Efeitos da nutrição mineral na competição inter e intraespecífica de Eucalyptus grandis e Brachiaria decumbens: 1- crescimento. Scientia Forestalis, 58, 49-57.

Coll, L., Balandier, P., \& Picon-Cochard, C. (2004). Morphological and physiological responses of beech (Fagus sylvatica) seedlings to grass-induced belowground competition. Tree Physiology, 24(1), 45-54. http://dx.doi.org/10.1093/treephys/24.1.45

Costa, A. G. F., Alves, P. L. C. A., \& Pavani, M. C. M. D. (2004). Períodos de interferência de trapoeraba (Commelina benghalensis Hort.) no crescimento inicial de eucalipto (E. grandis W. Hill ex Maiden). Revista Árvore, 28, 471-478. http://dx.doi.org/10.1590/S0100-67622004000400001

Cruz, M. B., Alves, P. L. C. A., Karam, D., \& Ferraudo, A. S. (2010). Capim-colonião e seus efeitos sobre o crescimento inicial de clones de eucalipto. Ciência Florestal, 20, 391-401.

Dinardo, W., Toledo, R. E. B., Alves, P. L. C. A. \& Pitelli, R. A. (2003). Efeito da densidade de plantas de Panicum maximum Jacq. Sobre o crescimento inicial de Eucalyptus grandis W. Hill ex Maiden. Scientia Forestalis, 64, 59-68.

Garau, A. M., Ghersa, C. M., Lemcoff, J. H., \& Barañao, J. J. (2009). Weeds in Eucalyptus globulus subsp. maidenii (F. Muell) establishment: effects of competition on sapling growth and survivorship. New Forests, 37, 251-264. http://dx.doi.org/0.1007/s11056-008-9121-8 
Pitelli, R. A., \& Marchi, S. R. (1988). Interferência das plantas invasoras nas áreas de reflorestamento. In: Seminário técnico sobre plantas daninhas e o uso de herbicidas em reflorestamentos. Rio de Janeiro, pp. 44-64.

Schweitzer, C., Gardiner, E., Stanturf, J., \& Ezel, L. A. (1999). Methods to improve establishment and growth of bottomland hardwood artificial regeneration. In J. Stringer, \& D. Lottis (Eds.) Proceedings 12th central hardwood forest conference (pp. 209-214). Lexington, Forest Service, Southern Research Station, USA.

Toledo, R. E. B., Alves, P. L. C. A., Valle, C. F., \& Alvarenga, S. F. (1996). Comparação dos custos de quatro métodos de manejo de Brachiaria decumbens em área de implantação de Eucalyptus grandis. Revista Árvore, 20, 129-141.

Toledo, R. E. B., Alves, P. L. C. A., Valle, C. F., \& Alvarenga, S. F. (1999). Manejo de Brachiaria decumbens e seu reflexo no desenvolvimento de Eucalyptus grandis. Scientia Forestalis, 55, 129-144.

Toledo, R. E. B., Victoria Filho, R., Alves, P. L. C. A., Pitelli, R. A., \& Lopes, M. A. F. (2000). Efeitos de períodos de controle de plantas daninhas sobre o desenvolvimento inicial de plantas de eucalipto. Planta Daninha, 18, 395-404. http://dx.doi.org/10.1590/S0100-83582000000300002

Toledo, R. E. B. , Dinardo, W., Bezutte, A. J., Alves, P. L. C. A. \& Pitelli, R. A. (2001). Efeito da densidade de plantas de Brachiaria decumbens Stapf. sobre o crescimento inicial de mudas de Eucalyptus grandis W. Hill ex Maiden. Scientia Forestalis, 60, 109-117.

Zen, S. (1987). Influência da matocompetição em plantas de Eucalyptus grandis. In Série Técnica IPEF, 4, 25-35.

\section{Copyrights}

Copyright for this article is retained by the author(s), with first publication rights granted to the journal.

This is an open-access article distributed under the terms and conditions of the Creative Commons Attribution license (http://creativecommons.org/licenses/by/3.0/). 